\title{
Rapport fra dødens forgårder
}

\author{
Historie skaper fellesskap og utdyper erfaringens betydning og mening. Noen hevder dess- \\ uten at historie er det som gjør vondt. Dag Skogheim har skrevet flere bøker om tuberku- \\ losens historie, både romaner og sakprosa. Selv om tiden er forbi da tæring var den store \\ folkesykdommen, er hans litteratur fortsatt viktig. Spennende er det å få mannen selv i tale.
}

$\AA$ møte en person som ble smittet av tuberkulose for snart 70 år siden, bringer opp noen vesentlige spørsmål. Hvordan ble sykdommen taklet av den enkelte og av samfunnet? Medisinsk sett dreier det seg om liggekur, pneumothorax og torakoplastikk der opptil åtte ribbein ble fjernet for å få lungene til å klappe sammen. Pasienten fikk høy status blant medpasienter etter «storoperasjonen», men hvordan taklet de dette på det mentale planet? Vi spør oss, men tør knapt tenke på svaret: Hvordan ville dagens 14-åringer taklet situasjonen om de brått ble sendt hjemmefra til «dødens forgårder» som tuberkuloseinstitusjonene ofte ble kalt? Sanatoriene var ofte isolert fra all annen bebyggelse, langt hjemmefra, steder der 14åringen knapt fikk besøk gjennom måneder og år. Medpasienter døde i nabosengen og egen skjebne var meget uviss.

- Ja, jeg er et klokt menneske, så ta du turen til Levanger for å intervjue meg. Jeg har gjort meg mange refleksjoner om legestanden gjennom årene, svarte Dag Skogheim da jeg ringte for å spørre om en intervjuavtale. Jeg stusset litt, hadde mannen mistet bakkekontakt på sine eldre dager? Kanskje er han en viktigper som vil belære oss om forhold som forlengst har mistet sin interesse? Hvem er han som så uforbeholdent mener han er et klokt menneske?

Men loddet var kastet og avtalen klar, dette fikk bære eller briste. Jeg ble invitert hjem til Dag Skogheim på den betingelsen at vi avsluttet ved 17-tiden, han arbeider helst ikke etter den tid. Det gjør han for å holde sikker døgnrytme.

\section{Diagnosen}

- I januar 1943, da du var 14 år gammel, fikk du diagnosen lungetuberkulose. Husker du hvordan du opplevde å få diagnosen?

- Jeg erindrer ikke at jeg tok det tungt, for tiden selv var så tragisk med krig og forferdelige hendelser. Min far hadde vært i fangeleiren Falstad der han ble torturert. I 1943, på ettersommeren, ble han igjen arrestert og sendt i fangenskap til Tyskland. At jeg i denne tiden fikk tuberkulose, påkalte ikke stor oppmerksomhet. Mange hadde det så uendelig mye verre. På en måte ble krigen en slags stabiliserende faktor i mitt liv fordi den ga mitt problem rett perspektiv. For øvrig fikk andre mennesker rundt meg andre alvorlige diagnoser, polio og difteri for eksempel. Til forskjell fra tuberkulose, der stillhet og tabu lå over det hele, var dette sykdommer som ikke hadde et tabu knyttet til seg, forteller han.

I de første to årene lå Dag Skogheim hjemme, isolert på et eget rom. Han hadde to yngre søstre. De måtte ikke bli smittet. Hans mor, med mannen i tysk fangenskap, la ned mye arbeid for å skaffe ham næringsrik mat, noe man mente var helt avgjørende i behandlingen av tuberkulose. Båndene til kamerater og kjente ble kuttet.

- Men det var et unntak: Jeg hadde en kamerat som kom nesten hver dag. Han trosset besøksforbudet, han var ikke redd tuberkulose. Han arbeidet $i$ et sykkelverksted og kom hver ettermiddag etter arbeids-

\section{«Det viktigste for menneskene er biblio- tekene, ikke medisinen»}

dagens slutt. Han kom ikke for å være «snill», men for å snakke om alt han hadde observert i løpet av dagen. Han berettet livlig, dette var spennende! I meg fikk han et glupende nysgjerrig publikum. Via min kamerat hadde jeg alltid oversikt over det som skjedde i den lille kystbyen. Fra den tid har jeg beholdt mitt sterke vitebegjær, jeg er nysgjerrighet på alt den dag i dag, betror Dag Skogheim meg mens vi nyter varm te i vakre keramikkrus med lekre små vannbakkels hans kone har satte frem.

- Slik var det bare og jeg erindrer det ikke som noen katastrofe, slår han fast uten dramatikk.

- Men hvordan klarte du å holde ut å ligge isolert på et rom i to år? Ungdom har jo et stort behov for nye impulser og et sosialt liv.

- Jeg vil si det slik: Jeg hadde for lengst oppdaget språksymbolenes verdier. Jeg leste alt som var å oppdrive og jeg utviklet en fabelaktig leseferdighet. Tro meg når jeg sier at jeg klarte å lese to sider samtidig! Dagene ble fylt med lesing, men helt usystematisk - aviser, blader, bøker. - For meg synes det som du fant en form for terapi i det å lese?

- Det ble bare sånn. Legen hadde sagt at jeg måtte ligge mest mulig. Det var definitivt. Under disse omstendighetene utviklet jeg nok vanen, trangen, det avgjørende ved det å lese. Da behøvde jeg ikke mer. Foreldrene mine var lesende mennesker. De abonnerte på aviser og blader og kjøpte bøker til meg.

\section{Forverring}

Da Dag Skogheim var 16 år gammel forverret tilstanden seg, og han ble vinteren 1946 sendt til Vensmoen sanatorium i Nordland.

- Oppholdet forandret livet mitt. Jeg var grundig understimulert etter to år med isolasjon hjemme. Nå oppdaget jeg at jeg ikke var alene om det å være syk. Selv om mye på sanatoriet var forferdelig, ble oppholdet en spennende tid, ja, en åpenbaring av hva livet kunne gi. Det var medpasientene, ikke legene og sykepleierne, som lærte meg om sykdommen. Det var jo dem jeg tilbrakte dagene sammen med. Vi som delte rom, var på ulike stadier av sykdommen. Jo mer behandling man hadde gjennomgått, jo høyere «status» fikk man blant medpasienter.

- I din bok Sanatorieliv har du en del selvbiografiske avsnitt som krydrer de mer generelle beskrivelsene av tuberkulosens kulturhistorie (1). Totalt sett gir du oss et godt inntrykk av de mer individuelle tragediene som utspant seg. Du beskriver også det paradoksale og irrasjonelle ved at livet på en måte blomstret opp for dem som måtte leve og kanskje dø på sanatoriene.

- Ja, vi var mennesker som plutselig skulle bo sammen, måned etter måned, ofte år etter år, ofte tett $i$ tett på seksmannsorm. Vissheten om at døden kunne inntreffe når som helst ble en kollektiv bevissthet som ikke nedfelte seg i den enkelte med stor angst og sorg. Vi klarte å holde en viss distanse til vår tragiske skjebne bl.a. ved det at vi ikke snakket om sykdommen og døden.

Vi snakket om det helt hverdagslige, vi hadde våre små problemer og gleder slik 


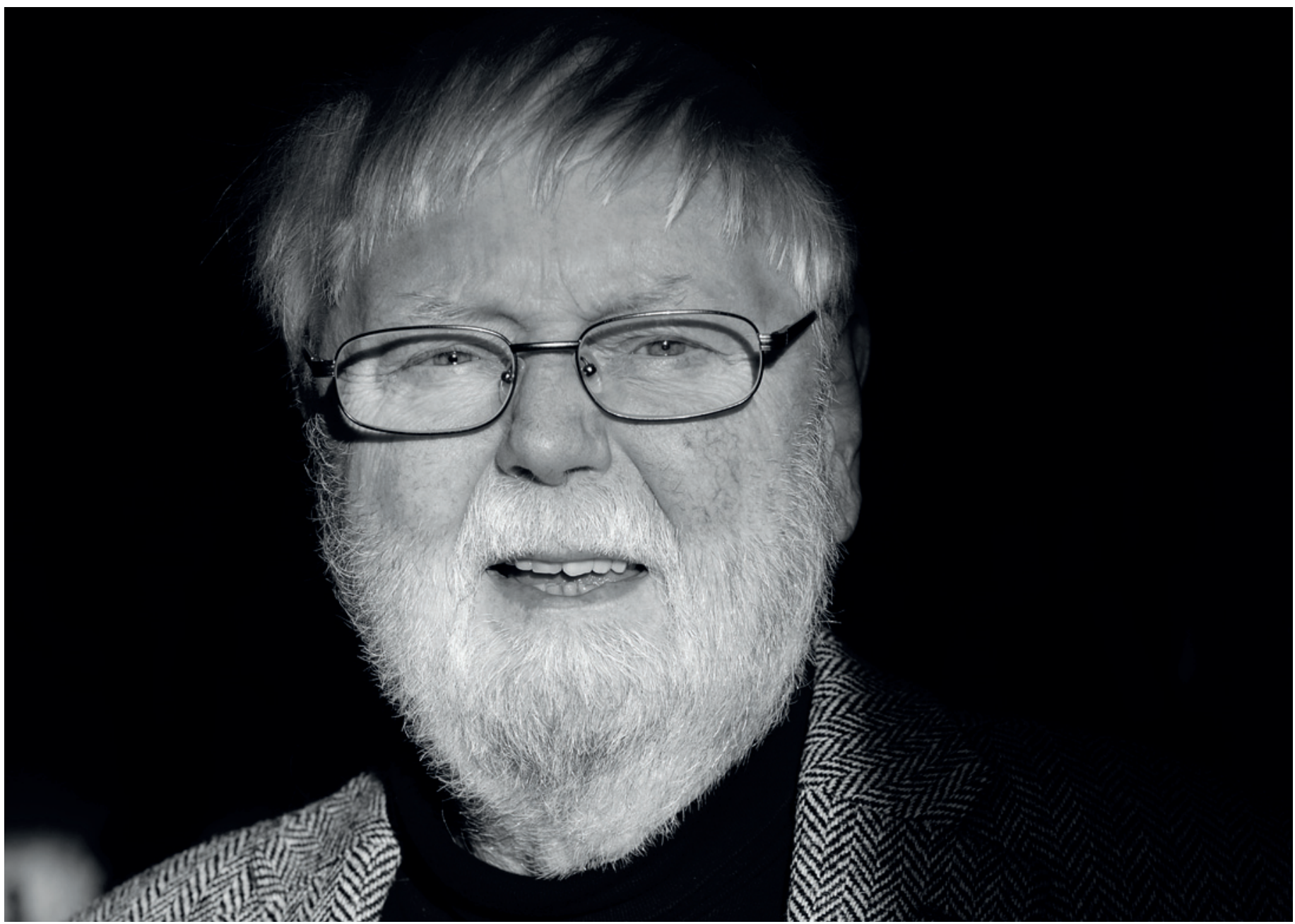

Foto Ned Alley/Scanpix

\section{Dag Skogheim}

Født 1928 i Sømna, sør i Nordland

- 1961-72 Lærer ved realskole og ungdomsskole

- 1970 Debuterte som forfatter

- 1991- Statsstipendiat

Mottatt en rekke priser for sitt forfatterskap

- Utgir ny bok i 2012 friske mennesker hadde det utenfor tuberkuloseinstitusjonene. Jeg var fullstendig klar over at jeg neppe hadde lenge igjen å leve, men du kan ikke ta slik erkjennelse innover deg dag ut og dag inn og la det være hovedinnholdet $\mathrm{i}$ hverdagen. Jeg tror ikke jeg hadde angst de 11 årene sykdommen varte, sier han ettertenksom og fortsetter: - Jeg vet ikke hva det er å lide av angst, men nylig opplevde jeg noe som skremte meg. Jeg kom til Oslo med toget. På stasjonen kom plutselig en mann mot meg, han var sint og rasende. Han kom rett mot meg. Da tenkte jeg at om han går løs på meg nå, har jeg ikke mulighet til å komme unna. Lungekapasiteten min er så liten at jeg ikke har noen sjanse. Han forsvant plutselig, men hjelpeløsheten jeg følte var svær. Når jeg nå er blitt «aldrende» forstår jeg virkelig de funksjonshemmedes maktesløshet i situasjoner du ikke kommer unna.

\section{Angsten}

- Men alle klarte vel ikke å takle sin egen skjebne så greit som du beskriver?

- Nei, noen gikk med nervene «utenpå seg». Jeg erindrer en som gikk og ventet på «storoperasjon». Han visste selvsagt hvor risikabelt det var. Han ble rasende for den minste ting, på grensen til det hysteriske.

Han irriterte seg grenseløst over at jeg lå og leste, alltid. - Hva faen jeg innbilte meg? Om jeg mente jeg var bedre enn andre? Han skremte meg virkelig. Dag Skogheim er full av historier og beskriver sine opplevelser så godt at jeg nesten føler jeg er til stede der det hendte.

- En kven ble innlagt på seksmannsrommet der jeg lå. Han var læstadianer, sang sine læstadianske salmer og ba halvhøyt til Gud. Han kunne ikke et ord norsk. Vi ble forbannet på kvenen; - Hold kjeft for faen! Han ble redd, og tidde absolutt. Jeg oppdaget senere at han brukte «dassen» som fristed for seg. Der kunne han be og synge når ingen andre var der. «Dassen» var det eneste stedet på sanatoriet der man kunne være alene med seg selv. Mange gikk dit når livet ble for hardt. På «dassen» kunne man til og med gråte i fred - på seksmannsrommet var du aldri alene. Alt som skjedde med deg der var allemannseie. 


\section{Forverring}

I 1947-48 ble Dag Skogheim kritisk syk med langvarig, høy feber. Han hadde stadige blødninger fra lungene.

- Også da ble jeg innlagt på et seksmannsrom. En av medpasientene sa at jeg hadde vært uheldig med sengen, seks personer som hadde hatt den før meg, hadde dødd i den. Den siste som døde fikk blodstyrtning, så voldsom at den sto helt opp i taket, som en fontene. Heldigvis var jeg på det tidspunkt en erfaren tuberkulosepasient. Jeg kjente til blødninger, at man kunne dø i løpet av få minutter. Uansett, det var voldsomt belastende å bli fortalt dette når jeg selv hadde blødninger. Måned etter måned var jeg høyfebril, med stadige blødninger. Høsten 1947 ble både dramatisk og tragisk. Mange medpasienter døde. Jeg visste det gikk nedover. I den tilstand jeg var, ville jeg neppe overleve. Stykker av tennene falt ut. Tæring! Alle som var oppegående holdt seg mest mulig borte fra rommet, akkurat som jeg ville gjort om en kamerat lå og blødde og var dødsens syk. Det sa seg selv at en så syk pasient måtte få all den ro som trengtes. Dessuten var det en svær påkjenning å høre surklingen av blod nede fra bronkiene. Slike situasjoner viste klart at man ikke hadde lenge igjen i livet. Men ungdommens veldige potensial styrte meg unna døden.

Han fortsetter historien med slik innlevelse at jeg føler trang til å gjøre noe for å stoppe blødningene, noen må da kunne gjøre noe! Gi ham i alle fall trøst!

- Når blodet surkler i lungene får du kvelningsfornemmelser, du må sette deg opp, tør ikke hoste. Du tenker at om du hoster, river du opp flere blodårer der inne. Dette pågikk i måneder. Jeg ble vasket og stelt i sengen, maktet ikke stå opp. Det var tæring! Klart man er redd for å dø under slike omstendigheter, men det er en tilvenningssak også. Man blir «avflatet» i forholdet til døden når man må leve med den så kloss innpå seg over lang tid.

\section{Stigmatiseringen}

- Det du forteller er vanskelig å forstå for oss som har vokst opp i en annen tid. Kan det å ha tuberkulose sammenliknes med noen av vår tids lidelser?

- Dagens infeksjonssykdommer er ikke tabuisert slik tuberkulosen var. Tuberkulosen var enestående. En ting var å få sykdommen, noe ganske annet var stigmatiseringen. Du og hele din familie ble rammet. Det at du kunne smitte andre nedfelte seg i deg. Jeg vil ikke si det var skam som preget oss, men det at du alltid måtte være forsiktig preget oss veldig. Vi visste at basillene kunne slynges ut bare vi snakket. Å hoste i nærheten av friske ble ansett som uansvarlig. Da jeg i 1949 ble utskrevet fra Grefsen folkesanatorium, sa overlege Folkestad til meg: «Du vet hva du har å gjøre. Ikke nys, host eller rop høyt. Jeg vet du kan ta dette ansvaret. Derfor får du reise hjem». Å si dette var bevisst fra hennes side. Hun visste at jeg ville bære det med meg ut i storsamfunnet.

- Det er et paradoks at det ser ut som moderne mennesker lider av angst og depresjon i langt høyere grad enn da du var ung. Du har tålt noe vi neppe ville tålt i dag. Hvordan kan dette forklares?

- Jeg tror det henger sammen med at forventningene har økt enormt i våre dager. Jeg vil si det så sterkt at jeg opplever det skamløst hva moderne mennesker forventer av livet. Det irriterer meg faktisk. Det ser ut som om enkelte forventer at alt skal legges til rette for at akkurat de skal få gode dager, sier Dag Skogheim med sterk røst.

\section{Forventninger i vår tid}

- Her har vel helsevesenet selv båret ved til bålet, rekker jeg så vidt å skyte inn før Dag Skogheim fortsetter så engasjert at ordene spyttes ut av munnen hans. Nå skulle overlege Folkestad sett ham!

\section{«Rundt tuberkulosen lå det alltid stillhet»}

- Nei, jeg tror ikke helsevesenet har ansvaret her. Det er vår utrolige økonomiske utvikling som gjør at ikke noe blir bra nok for moderne mennesker. Jeg mener alle klagene som i dag rettes mot helsevesenet i det store og hele er ensidige og dermed meningsløse. Mine egne forventninger er ikke så store når det gjelder sykdom og helse. Jeg regner ikke med at legevitenskapen egentlig har så mye å tilby om jeg skulle få en alvorlig sykdom. Viktigst er det at noen er der og tar imot syke mennesker med høflighet og kompetanse. I min tid var overlegene virkelig konger i sitt «revir». De visste de ikke kunne gjøre mye, men var også klar over at de hadde voldsom autoritet som gjorde at de syke stolte på dem. Da kunne det nok hende at medisinen de forskrev også hjalp. Tiden preger oss nok mer enn vi vil innrømme.

\section{A akseptere sin skjebne}

\section{- I 11 år var du tuberkulosepasient. Du} gjennomgikk det som var av datidens behandlingsregimer. Hvordan har det satt preg på deg i ettertid?

- Det er det helt umulig å svare på. Jeg vet ikke hvordan jeg ville utviklet meg om jeg hadde vært frisk i ungdomstiden. Mitt privilegium var at jeg hadde glede av å omgås språksymbolene. Sykdommen skapte nok en egen karakter i meg og jeg hadde ungdommens potensial til å takle livet slik det ble. Husk det var en tid da man måtte akseptere det legen sa uten å stille spørsmål. Jeg tilhører en generasjon som godtok sin skjebne uten å kny. Min far var militært utdannet. Han likte orden i rekkene. Legen min på hjemstedet var en mann av svært, svært få ord. Jeg visste at behandlingen av sykdommen ikke var noe jeg kunne opponere mot. I etterkant tenker jeg at du verden så lite det hadde for seg, sanatorieregimet.

\section{Vår tids leger}

- Datidens leger hadde en annen væremåte enn i våre dager. Hvordan ser du på denne forskjellen?

- Både leger og sykepleiere jeg møtte kunne være direkte slemme, men jeg måtte bare godta deres oppførsel uansett om jeg ble forbannet og krenket over måten de behandlet meg på. Til sammenlikning synes jeg vi i dag har et førsteklasses helsevesen. Jeg blir tatt godt imot av høflige, vennlige mennesker. Snart er jeg 84 år, har lite plager og min fastlege dekker alle mine behov. Jeg ble hjulpet til høreapparat i november, tilpasset og med fin instruksjon. Det er storslagent! To ganger i året er jeg hos min lungelege som «sjekker» meg og gir meg «status» per dato. For meg som tidligere «tubist» betyr det mye. To ganger i året er jeg til kontroll for en utposing i magen. Alt foregår smidig og rolig, dette er veldig bra!

Som lege er det en dyd å forstå sine pasienter. Dette idealet er jo uoppnåelig, Men de fleste av oss prøver. Om vi lykkes vet vel pasientene bedre enn oss, så det er fristende å spørre : - Føler du at vi som er yngre enn deg forstår hva du har gjennomlevd?

- Siden du spør, vil jeg si det er umulig for dere å forstå det. Om dere ønsker innsikt i tuberkulosens herjing med menneskene tror jeg det ville gjøre dere til bedre leger, men personlig venter jeg ikke at dere kan ha denne innsikten. Men du finner den i bibliotekene - innsikten og oversikten fra oldtid til i dag.

Når klokken nærmer seg 17 vet jeg at min tid snart er oppbrukt. Kontoret er fylt med bøker fra gulv til tak. En vegg er tapetsert med utallige tidsskriftordnere hvor innholdet er nøye merket på fremsiden. Han viser meg sitt arbeidsrom og kommer plutselig på at han hadde sagt han hadde noe å lære oss leger. Han koker det ned til én setning, til det som for ham er vesentlig:

- Det viktigste for menneskene er bibliotekene, ikke medisinen.

Jeg kjenner at Dag Skogheim faktisk har rett: Han har mye å lære bort til oss leger.

\section{Jannike Reymert}

jannike.reymert@ntebb.no

Bakklandet legekontor

\section{Litteratur}

1. Skogheim D. Sanatorieliv. Fra tuberkulosens kulturhistorie. Oslo: Tiden, 2001 